"Is too much competition bad for the industry? A Taiwanese banking case"

\begin{tabular}{|c|c|c|}
\hline AUTHORS & $\begin{array}{l}\text { Paul M.S. Choi } \\
\text { Seth H. Huang }\end{array}$ & \\
\hline ARTICLE INFO & \multicolumn{2}{|c|}{$\begin{array}{l}\text { Paul M.S. Choi and Seth H. Huang (2016). Is too much competition bad for the } \\
\text { industry? A Taiwanese banking case. Investment Management and Financial } \\
\text { Innovations, } 13(2-1), 128-140 . \text { doi:10.21511/imfi.13(2-1).2016.01 }\end{array}$} \\
\hline DOI & \multicolumn{2}{|c|}{ http://dx.doi.org/10.21511/imfi.13(2-1).2016.01 } \\
\hline RELEASED ON & \multicolumn{2}{|l|}{ Monday, 04 July 2016} \\
\hline JOURNAL & \multicolumn{2}{|c|}{ "Investment Management and Financial Innovations" } \\
\hline FOUNDER & \multicolumn{2}{|c|}{ LLC "Consulting Publishing Company "Business Perspectives" } \\
\hline & & $\begin{array}{l}=-: \\
= \pm=\end{array}$ \\
\hline NUMBER OF REFERENCES & NUMBER OF FIGURES & NUMBER OF TABLES \\
\hline
\end{tabular}

(c) The author(s) 2023. This publication is an open access article. 
Paul M.S. Choi (Republic of Korea), Seth H. Huang (Republic of Korea)

\title{
Is too much competition bad for the industry? A Taiwanese banking case
}

\begin{abstract}
The authors examine the relationship between net interest margin, a measure of banks' pricing power, and lending market shares in the environment of regulation changes in Taiwan from 1991 to 2009. Specifically, the effect on net interest margins from mandatory industry consolidation is studied in depth. The authors find that firm market shares in the first period have positive and highly significant impacts on the bank profitability, but for the second period, the authors find increased non-performing loans. During the second period, the credit lending market share became a main profit component but with a negative impact on profitability. Additionally, the focus of lending type shifted from collateralized to credit lending, a type of lending that has much higher profitability, but such lending has negative and significant effects on banks' profitability. The results suggest a mandatory industry-wide consolidation affected the bank lending types, with banks focusing more on increasing short-term market share through credit lending than on profitability.
\end{abstract}

Keywords: net interest margin, banking, competition, Taiwanese banking industry. JEL Classification: G21, L11.

\section{Introduction}

Before 1989, most Taiwanese banks were stateowned. In that year, the government deregulated the banking industry and allowed the establishment of new banks. The policy officially came into effect in 1991 and drastically lowered the industry's barriers to entry. By year 2000, there were over 50 banks, resulting in a high industry fragmentation.

In such a competitive environment, bank profit proxy, the net interest margin (NIM), eroded throughout the 90s. Interest payments from loans were the biggest income source for banks, and the decrease in NIMs directly affected the returns on equity (ROE). Based on the data provided by the Financial Supervisory Commission and the Central Bank in Taiwan, in 1993 the seven state-owned major banks had an average ROE of $22.90 \%$ and the domestic non-state-own average was $12.46 \%$. In 2000 , the domestic average declined to $6.19 \%$ in $2000,-6.93 \%$ in $2002,10.30 \%$ in 2004 and $1.95 \%$ in 2006.

Recognizing the problem, the government began a series of actions to meet these challenges. One law that was passed was the Financial Holding Company Act. After the passage of the Financial Holding Company Act in 2001, fourteen financial holding companies were established, owning banks, insurers or securities firms. The government

(C) Paul M.S. Choi, Seth H. Huang, 2016.

Paul M.S. Choi (first author), Assistant Professor, College of Business Administration, Ewha Womans University, Republic of Korea.

Seth H. Huang (corresponding author), Assistant Professor, College of Business Administration, Ewha Womans University, Republic of Korea.

Special thanks are due to Warren B. Bailey and Robert Masson. This research is based on Seth H. Huang's Ph.D. dissertation at Cornell University. This work was supported by the Ministry of Education of the Republic of Korea and the National Research Foundation of Korea (NRF-2015S1A5A2A01010876). Standard disclaimer rules apply and all errors are of our own. purposefully allowed the creation of such powerful financial conglomerates in hopes of seeing accelerated consolidation in the banking industry. However, the passage of the act did not facilitate the banking industry consolidation to an ideal level. After eight years, there are still 37 banks in Taiwan as of 2009, a number greater than other Asian countries such as Hong Kong, Singapore, Japan and South Korea. In these countries, the total assets market share of the three largest banks was $63 \%$ in South Korea, $83 \%$ in Hong Kong, $72 \%$ in Singapore, $68 \%$ in Australia, but only $16 \%$ in Taiwan (Hwang and $\mathrm{Wu}, 2007$ ). Moreover, the state-owned banks continued to hold the majority market shares.

Due to the Asia Financial Crisis, the banking industries in many industrialized countries went through significant changes since 2000. During this period, bank consolidations and high net interest margins have been the special characteristics for the financial markets in developing countries ${ }^{1}$.

Demsetz (1973) points out that just as with patents any innovations which lead to either superior technologies (low production costs) or superior products can lead to some firms enjoying the economics rents from their insights through individual firm (not collective) market power. His insight was that this could lead to a firm developing a higher market share and higher profits. The result could then be that industry concentration rises and industry profits rise, the correlation between

\footnotetext{
${ }^{1}$ Demirguc-Kunt and Huizinga's (2000) empirical study finds that, for countries with underdeveloped financial systems, a move toward a more developed financial system reduces bank margins and profitability. More specifically, in developing countries, both the banks and stock markets are less developed, and the greater the development of a country's banks, the harsher is the competitive environment, the greater is the efficiency, and the lower are the bank margins and profits.
} 
concentration and profits could be due to market power, but unilateral market power rewarding successful entrepreneurial competition, a desired outcome just as with the patent system ${ }^{2}$.

What is the likely explanation for the concentration profits relationships found in the literature, collective market power or unilateral market power? Scherer and Ross (1990) state that this is the "main question" in empirical industrial organization in the latter part of the twentieth century. Their conclusion is that the Demsetz hypothesis "wins" the day with them saying that market "power appears to be wielded not collectively..." Although Jakubson, Jeong, Kim and Masson (2009) have a working paper which questions this (for Korean data) we will not pursue the issue in detail.

In this paper, we investigate how NIMs are affected by different types of market shares, macroeconomic variables and financial market structures, controlling for several firm-specific variables such as bank financial structures and lending practices. Then we will move on to different types of market concentration to examine the relationship between NIMs and market concentration.

\section{Literature review}

Recent research, as surveyed by Levine (1997), shows that the efficiency of financial intermediaries can affect economic growth. Specifically, banks affect the net returns on savings and determine the required returns on investments. In order to achieve efficiency and service corporations, banks have to be sufficiently large to achieve the economies of scales which reduce operating costs. Bank consolidation waves in Hong Kong, Korea and Japan have produced some of the largest and competitive financial institutions in the world.

Berger and Hannan (1989) and Hannan (1991) study how U.S. banks in more concentrated local markets charge higher rates on corporate loans and pay lower rates on retail deposits, resulting in higher NIMs. Many papers have focused on the impacts of concentration on the degree of competition in the banking sector and bank profitability. DemirgüçKunt, Laeven and Levine (2004) analyzed the effects of concentration and bank regulation on U.S. bank spreads.

As for NIMs, Hanson and Rocha (1986) summarize the role that implicit and explicit taxes play in raising spreads and discuss some of the

\footnotetext{
${ }^{2}$ Dixit (1986) shows that with heterogeneous goods outcomes are highly dependent upon demand structures. So, for example, if Porsche comes out with a superior product it will gain higher profits and its very small share will increase, possibly eroding industry concentration. We ignore such effects.
}

determinants of bank costs and profits, such as inflation, scale economies and market structure. The authors use aggregate interest data for 29 countries between 1975 and 1983; they find a positive correlation between NIMs and inflation.

Barth, Nolle and Rice (1997) use 1993 data from 19 industrial countries to study the impacts of banking power on bank returns on equity controlling for several bank and market characteristics. They find that variations in bank power, concentration, and the existence of explicit deposit insurance do not significantly affect the return on bank equity. However, their study does not control for many important variables that affect the base lending rates.

Kunt and Huizinga (1999) use bank-level data of 80 countries from 1988 to 1995 to show that differences in NIMs and bank profitability reflect a variety of determinants: bank characteristics, macroeconomic conditions, explicit and implicit bank taxation, deposit insurance regulation, overall financial structure and underlying legal and institutional indicators. They find that a larger ratio of bank assets to gross domestic product and a lower market concentration ratio lead to lower margins and profits, controlling for differences in bank activity, leverage and the macroeconomic environment.

Mergers or consolidations increase market concentration, which increase banks' market power (by collusion, tacit or explicit) and theoretically create more unfavorable prices for customers on deposits and loans. Alternatively, banks may also reach better economies of scale and efficiency savings that may be passed on to customers. Prager and Hannan (1998) find that M Activities increased local concentration in U.S. banking markets and had unfavorable price effects for consumers. Others such as Akhavein, Berger and Humphrey (1997) find mixed or insignificant effects of M \& A effects on prices in the U.S. Sapienza (2002) also finds mixed results for the Italian banking industry. Panetta and Focarelli (2003) explain that, based on their empirical research on the Italian banking sector, short-run effects of M \& As may have shortrun effects on prices that are unfavorable to customers, but that the long-run effects were favorable due to efficiency gains. In short, their logic is that the market power effects dominate in the short-run and the efficiency effects dominate in the long term.

Demirgüç-Kunt, Laeven and Levine (2004) examine the impact of bank regulations, concentration and national institutions on bank NIMs using data on 1400 banks across 72 countries. The results show 
that tighter regulations on bank entry, restrictions on bank activities and regulations that limit the freedom of bankers to conduct their business all boost NIMs.

\section{Data and methodology}

\section{Data}

We use National Taiwan University's databases. One includes the monthly data on the operational information such as bank lending rates, bank deposit rates, the deposit market shares, lending, depositing amounts and etc. The other database extracts the information from banks' quarterly filings; it has the basic performance measures, profitability and cost structure on a quarterly basis. To utilize all available information, we replace the missing values based on the information available at the last observation. Aside from the above adjustments, there are no other modifications done to the datasets. In this study, we use observations between 1991 and 2009 and end up with 5081 observations in total.

\section{Empirical model and variables}

This paper uses panel data regression with fixed effects to analyze the impacts of various types of market shares on bank NIMs. The pricing power is conventionally defined as the net interest margin, also called the bank spread. This study controls for a host of bank characteristics and macroeconomic variables by estimating regressions of the following form (base model):

$$
\begin{aligned}
& \text { NIM }_{i, t}=\alpha_{0 i}+\alpha_{1} \text { Debt to Assets Ratio }_{i, t} \\
& +\alpha_{2} \text { NPLPercentage }_{i, t}+\alpha_{3} \text { Service to Interest Income Ratio }_{i, t}+ \\
& +\alpha_{4} \text { Administrative Cost Percentage }_{i, t}+ \\
& +\alpha_{5} \text { Discount Rate }_{t}+\alpha_{6} \text { Base Lending Rate }_{t}+ \\
& +\alpha_{7} \text { Market Share }_{i, t}+\alpha_{8} \text { Liquid Ratio }_{i, t}+\epsilon_{i, t}
\end{aligned}
$$

where $i$ is the bank ID, $t$ refers to the time period considered in monthly frequency. Equation (1) is motivated by the dealership model of bank spreads developed by Ho and Saunders (1981), extended by Allen (1988), Angbazo (1997) and others, and the firm theoretical framework developed by Zarruck (1989) and Wong (1997). The two models predict how operating costs, regulatory costs, credit risks and market structure can affect interest spreads. Their models are modified in this paper, and we use ex ante NIMs whereas they use ex post NIMs.

The NIM is the difference between the weightedaverage lending rate of the month, which is defined as the ex-ante weighted-average contractual lending rates and weighted-average lending rate on new loans, and the average deposit rate of the month, which is defined as the ex-ante weighted-average contractual deposit rates and weighted-average lending rate on new deposits.

The debt-to-asset ratio is the ratio of total debt (bank liabilities) to total assets.

The NPL percentage is the ratio of non-performing loans to total loans. Non-performing loans include the preexisting and current NPLs. NPLs typically only stay on a bank's balance sheet for a couple years, and then are written down at the discretion of bank managers or partially recovered by collection agencies. This variable captures the credit risk imbedded in the preexisting bank portfolio, which may likely affect the bank's attitude toward future risks and types of customers. This variable is often included in the literature, but it is especially important since we are using ex ante NIMs. The NPL in this case captures the differing portfolio risks. Specifically, banks will charge higher rates of interest on riskier loans so banks with riskier loans and facing similarly riskier loans in the future will have higher average NIMs.

The discount rate is the government's marginal lending rate to banks, and it is set by the central bank. It is a fixed rate for banks to borrow money from the central bank. It is also called the interest rate for "discount window lending."

The base lending rate is targeted by the central bank. This interest rate is also known as the "federal funds rate," and it is the shot-term rate at which the banks lend to each other. It is also known as the minimum lending rate and serves as the basis for debtors to refinance loans, meaning that a higher base lending rate should have a positive relationship with the NIMs. The liquid ratio is measured as the ratio of liquid assets to total assets.

Four different kinds of market shares are used. There are the average monthly deposit market share, the bank branch market share (out of total branches in the country), credit lending market share and collateralized lending market share. The first two are concerned with the absolute bank size in the industry, and the latter two address the bank lending practices. The average monthly deposit market share is the market share of the total deposits a bank has in the financial market. Bank branch market share is selfexplanatory, though not often used in the literature. The bank branch market share is important in Taiwan since online banking is not yet prevalent in Taiwan, and most customers have to go to a physical location to receive banking services. Credit lending and collateralized lending market shares are the market shares of how much credit loans and collateralized loans a bank makes in a month. To our knowledge, these two explanatory variables have never been used in the literature. Table 1 summarized the representative statistics of our sample. 
Table 1. Sample statistics

\begin{tabular}{|l|c|c|c|c|c|}
\hline \multicolumn{1}{|c|}{ Variable } & Obs & Mean & Std. dev. & Min. & Max. \\
\hline NIMs & 5278 & 3.571449 & 2.339307 & 0 & 64 \\
\hline Debttoassets ratio & 5272 & 89.76445 & 11.46907 & 0.73 & 99.17 \\
\hline NPL percentage & 5278 & 3.001228 & 2.432975 & 0 & 16.33 \\
\hline Service/interest income & 5242 & 0.0571841 & 0.052747 & 0 & 0.779462 \\
\hline Administrative cost/total revenue & 5260 & 23.23901 & 7.73967 & 0 & 64.17 \\
\hline Discount rate & 5278 & 3.575374 & 1.550582 & 1.25 & 6.25 \\
\hline Baselending rate & 5278 & 6.08897 & 1.898596 & 3.162 & 8.647 \\
\hline Credit/collateralized lending & 5042 & 9.644629 & 69.92915 & 0 & 556.5624 \\
\hline Liquid ratio & 5272 & 0.2645425 & 0.0972346 & 0.0317914 & 0.9690241 \\
\hline Loss reserve ratio & 5199 & 1.231333 & 0.7663322 & 0 & 10.42 \\
\hline Total assets growth & 5260 & 15.03355 & 36.75141 & -38.76 & 902.81 \\
\hline Lending to deposit ratio & 5244 & 90.19424 & 36.0609 & 0 & 508.93 \\
\hline Bank asset to GDP & 5149 & 5210.793 & 1385.181 & 818.3441 & 7586.106 \\
\hline GDP growth rate & 5149 & 4.721824 & 4.214922 & -9.88 & 12.62 \\
\hline Stockcap to GDP ratio & 5149 & 0.7818385 & 1.335686 & 0.1760109 & 7.555964 \\
\hline Monthly total assets & 5279 & $1.35 \mathrm{E}+10$ & $5.37 \mathrm{E}+09$ & 0 & $2.15 \mathrm{E}+10$ \\
\hline Mkt share of credit lending & 5230 & 0.0397706 & 0.0495375 & 0 & 0.4465027 \\
\hline Mkt share of collateralized lending & 5230 & 0.0397706 & 0.0485395 & 0 & 0.6360543 \\
\hline Log total branches & 4754 & 7.929741 & 0.19211 & 7.499424 & 8.105609 \\
\hline Average monthly market share (\%) & 5117 & 2.214688 & 2.036833 & 0 & 9.21 \\
\hline Bank branch market share & 4651 & 0.0234938 & 0.0171975 & 0.0006037 & 0.0919118 \\
\hline
\end{tabular}

\section{Net interest margin and profitability}

Most papers use ex-post spreads because the ex-ante spreads, determined by contractual agreements, are not available. The ex-post spread is the difference between the implicit average interest charged on loans and the implicit average interest paid on deposits. But the ex-post spread in reality does not represent the pricing power of banks. There are several shortcomings. First, the interest received by a bank already incorporates default risks - when a debtor defaults, a bank does not receive interest. Second, the interest rate received by a bank during the quarter does not represent the bank's pricing power - the bank can be receiving interest this quarter from a loan made years ago.

\section{Empirical results}

Average monthly deposit market share and branch market share
The data is divided into two periods. The first financial reform, which warned the industry of an imminent industry consolidation, began in 2001. Itinduced the banks to engage in fierce competition for market shares through lowering the collateralized lending rate as indicated in our analysis, essentially turning into a price war. Therefore, after 2001 one may expect the deposit market share to have a negative impact on NIMs because the kind of market share was earned by lowering the NIMs. Since the consolidation progressed quite slowly, this price war became a continuous practice, causing the banks to have very low profitability. The subperiods are a unique aspect of this study. By doing so, we can capture the structural shifts of the industry and conduct analysis without assuming there were not structural shifts, common shocks or time trends.

Table 2. Deposit and branch market shares - base model

\begin{tabular}{|c|c|c|c|c|c|c|}
\hline & \multicolumn{3}{|c|}{ Average monthly deposit market share } & \multicolumn{3}{|c|}{ Bank branch market share } \\
\hline & All & $1991 \sim 2000$ & 2001 2009 & All & $1991 \sim 2000$ & 2001 2009 \\
\hline \multirow{2}{*}{ Debt-to-asset ratio } & $-0.06503^{* * *}$ & $-0.03433^{\star * *}$ & $-0.06772^{\star * *}$ & $-0.18554^{\star * \star}$ & $-0.23689^{* * *}$ & $-0.07322^{* * *}$ \\
\hline & $(15.51)$ & $(4.95)$ & $(11.19)$ & $(43.33)$ & $(38.98)$ & $(11.89)$ \\
\hline \multirow{2}{*}{ NPL percentage } & $0.06416^{\star \star \star}$ & 0.01672 & $0.12501^{\star \star *}$ & $0.11648^{\star \star \star}$ & 0.04651 & $0.12597^{\star \star \star}$ \\
\hline & $(7.05)$ & $(1.02)$ & $(13.57)$ & $(10.26)$ & $(1.64)$ & $(13.55)$ \\
\hline \multirow{2}{*}{ Service interest to total income } & $3.64992^{* * \star}$ & $11.69017^{\star \star \star}$ & $2.33535^{* * *}$ & $4.44110^{\star \star *}$ & $27.34636^{\star \star \star}$ & $2.23780^{* * *}$ \\
\hline & $(7.06)$ & $(8.68)$ & $(5.13)$ & $(7.27)$ & $(13.98)$ & $(4.82)$ \\
\hline \multirow{2}{*}{ Administrative cost percentage } & $0.03917^{\star \star \star}$ & $0.16737^{\star \star \star}$ & $-0.03520^{* * *}$ & $0.01251^{\star \star \star}$ & $0.15853^{\star \star \star}$ & $-0.03369^{* \star *}$ \\
\hline & $(11.35)$ & $(21.89)$ & $(9.89)$ & (2.93) & $(12.02)$ & $(9.27)$ \\
\hline \multirow{2}{*}{ Discount rates } & $-0.05206^{\star \star \star}$ & $-0.51979^{\star \star \star}$ & $-0.11768^{\star \star \star}$ & -0.02824 & $-0.47715^{\star \star \star}$ & $-0.10248^{\star \star \star}$ \\
\hline & (2.68) & $(8.86)$ & $(5.00)$ & $(1.22)$ & $(5.22)$ & $(4.27)$ \\
\hline
\end{tabular}


Table 2 (cont.). Deposit and branch market shares - base model

\begin{tabular}{|c|c|c|c|c|c|c|}
\hline & \multicolumn{3}{|c|}{ Average monthly deposit market share } & \multicolumn{3}{|c|}{ Bank branch market share } \\
\hline & All & $1991 \sim 2000$ & $2001 \sim 2009$ & All & $1991 \sim 2000$ & 2001 2009 \\
\hline \multirow{2}{*}{ Base lending rate } & $0.14704^{\star \star \star}$ & $0.77028^{\star \star *}$ & $-0.09895^{\star \star *}$ & 0.01795 & $0.59308^{\star \star *}$ & $-0.10413^{\star \star \star}$ \\
\hline & $(8.24)$ & $(8.80)$ & $(6.17)$ & $(0.85)$ & $(3.60)$ & $(6.38)$ \\
\hline \multirow{2}{*}{ Liquid ratio } & $6.37397^{\star * *}$ & $5.24137^{* * *}$ & $2.07630^{* \star *}$ & $6.80676^{* * *}$ & -0.24302 & $2.42186^{* \star *}$ \\
\hline & (24.53) & $(10.44)$ & $(7.48)$ & $(21.40)$ & $(0.30)$ & $(8.19)$ \\
\hline \multirow{2}{*}{ Average monthly Mkt share } & $0.15968^{* * *}$ & $0.12501^{* *}$ & $-0.22880^{\star \star \star}$ & & & \\
\hline & $(5.97)$ & (2.26) & $(6.44)$ & & & \\
\hline \multirow{2}{*}{ Bank branch Mkt share } & & & & $0.48439^{\star \star \star}$ & $0.56965^{\star \star \star}$ & $-0.06160^{*}$ \\
\hline & & & & (14.73) & $(5.58)$ & $(1.90)$ \\
\hline Observations & 5081 & 2290 & 2791 & 4621 & 1802 & 2819 \\
\hline Number of Banks & 32 & 29 & 32 & 32 & 29 & 32 \\
\hline R-squared & 0.23392 & 0.49333 & 0.24600 & 0.39503 & 0.59988 & 0.23167 \\
\hline
\end{tabular}

Notes: Average monthly deposit and branch market shares are used as the explanatory variables of interest. The regression model uses fundamental bank information, excluding macroeconomic and lending practice information. Absolute value of $t$ statistics in parentheses* significant at $10 \%$; ** significantat 5\%; *** significant at $1 \%$.

Tables 2, 3 and 4 report the results of panel regressions based on the first two market share types. The three Tables are based on three different model specifications; Table 2 is based on firm characteristics (base model), Table 3 adds control variables based on lending practice information, and Table 4 adds more control variables based on macroeconomic data.

Table 2 reports the results of the base model. Two types of market shares are included: the average monthly deposit market share and the bank branch market share. The average monthly deposit market share is measured by a bank's total deposit amount over the total deposits owned by the entire industry. The second type of market share is the bank branch market share. This proxy is rarely used, but in practice, the more branches a bank has, the more convenient it is for depositors to engage in daily transactions. A higher bank branch market share may give a bank some power to price the loans higher since consumers may not compare the lending rates of all banks before making a borrowing decision. Also, the branch market share is important because first, depositors can sacrifice some pricing advantages for convenience, and second, a bank with a high branch market share may have a more established reputation in the marketplace, and depositors may not compare different deposit rates and go directly with large banks, implicitly ceding pricing power to the banks. More branches, customers may find a bank more convenient and deposit their money at the bank. With the higher demand for deposits, the bank may effectively lower the deposit rates and enjoy higher NIMs. Later we will control for different lending practices to see which types of market shares directly impact the NIMs.

The average monthly market share and bank branch market share both have positive and significant impacts on NIMs for the entire sample and between 1991 and 2000. But from 2001 to 2009, the average monthly market share has a negative impact on NIMs. In Taiwan, after the first financial reform, according to Current Asian Banker Analysis's publication in 2006, banks began issuing credit cards and cash cards because they yielded higher interests. Gradually, banks' operations became largely focused on credit lending. The fact that the average monthly market share has a negative impact from 2001 to 2009 may potentially be attributed to the changing lending practice from collateralized lending to credit lending. As Taiwanese banks became more leveraged and focused on credit lending, the deposit and branch market shares became less relevant. Following Figure 1 is a chart of the historical credit lending to total lending ratio based on National Taiwan University's database. 


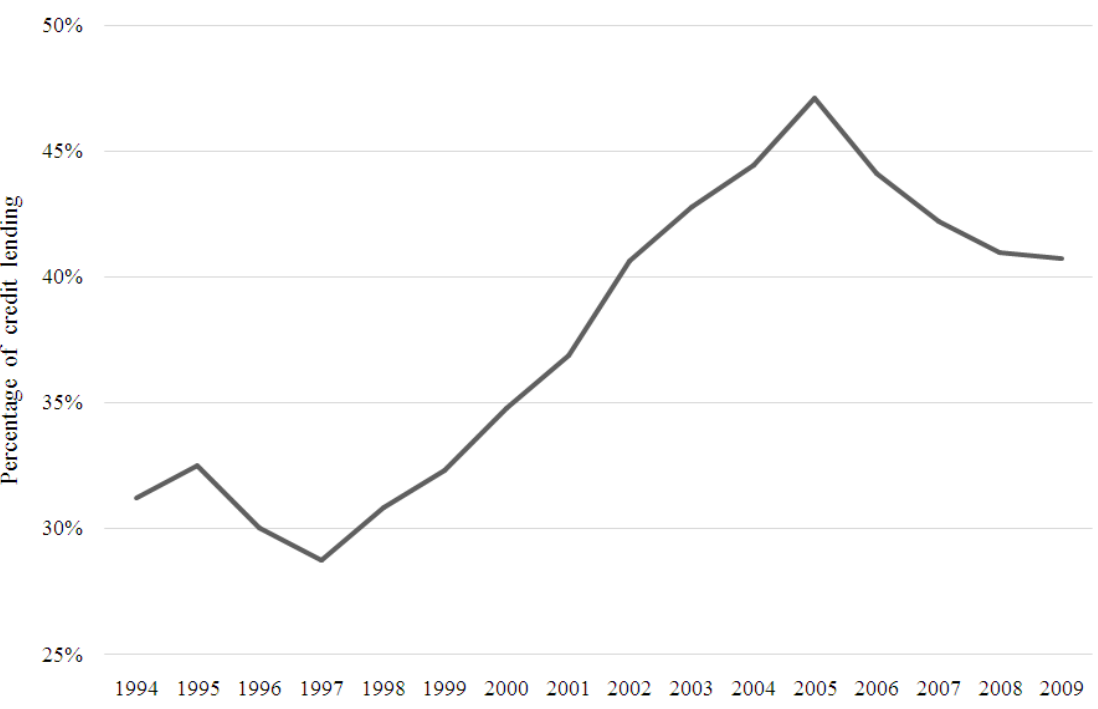

Fig. 1. Credit lending to total lending: historical percentage

Table 3 adds several more control variables. With regression model includes the variables from the these additional variables, samples and sub-sample base model and four other variables that are related panel regressions all have improved R-squares. This to a bank's internal operation and lending practices.

Table 3. Deposit and branch market shares - adding lending practice information

\begin{tabular}{|c|c|c|c|c|c|c|}
\hline & \multicolumn{3}{|c|}{ Average monthly deposit market share } & \multicolumn{3}{|c|}{ Bank branch market share } \\
\hline & All & 1991 2000 & 2001 2009 & All & $1991 \sim 2000$ & 2001 2009 \\
\hline \multirow{2}{*}{ Debt-to-asset ratio } & $-0.03246^{\star \star \star}$ & $-0.03401^{\star \star \star}$ & $-0.06153^{\star \star \star}$ & $-0.18169^{\star \star \star}$ & $-0.21607^{\star \star \star}$ & $-0.06725^{\star \star \star}$ \\
\hline & (7.09) & $(5.10)$ & $(10.35)$ & $(43.43)$ & $(37.26)$ & $(11.08)$ \\
\hline \multirow{2}{*}{ NPL percentage } & $0.06000^{\star * \star}$ & $0.07866^{\star \star \star}$ & $0.12781^{\star \star \star}$ & $0.11713^{\star \star \star}$ & $0.13906^{\star \star \star}$ & $0.12817^{\star \star \star}$ \\
\hline & $(6.58)$ & $(5.13)$ & $(13.73)$ & $(10.41)$ & $(5.19)$ & $(13.63)$ \\
\hline \multirow{2}{*}{ Service interest to total income ratio } & $3.92158^{\star * *}$ & $13.12071^{\star * \star}$ & $1.40197^{\star \star \star}$ & $4.14365^{\star \star \star}$ & $25.60361^{* \star *}$ & $1.35685^{\star \star \star}$ \\
\hline & $(7.49)$ & $(9.57)$ & $(2.98)$ & $(6.71)$ & $(12.75)$ & $(2.83)$ \\
\hline \multirow{2}{*}{ Administrative cost percentage } & $0.03305^{\star \star \star}$ & $0.15423^{\star \star \star}$ & $-0.02727^{\star \star \star}$ & $0.00750^{*}$ & $0.12635^{\star \star \star}$ & $-0.02594^{* \star \star}$ \\
\hline & $(9.61)$ & (22.34) & $(7.73)$ & $(1.79)$ & $(10.46)$ & $(7.18)$ \\
\hline \multirow{2}{*}{ Discount rates } & $-0.07128^{\star \star \star}$ & $-0.28636^{\star \star \star}$ & $-0.06618^{\star \star \star}$ & $-0.04543^{* *}$ & -0.07021 & $-0.05204^{* *}$ \\
\hline & $(3.66)$ & $(4.95)$ & $(2.83)$ & $(1.99)$ & $(0.72)$ & $(2.18)$ \\
\hline \multirow{2}{*}{ Base lending rate } & $0.15457^{\star \star *}$ & $0.57027^{\star \star \star}$ & $-0.09410^{* * \star}$ & 0.00426 & $0.31988^{\star *}$ & $-0.09636^{* * *}$ \\
\hline & $(8.95)$ & $(6.80)$ & $(6.01)$ & $(0.21)$ & $(2.11)$ & $(6.04)$ \\
\hline \multirow{2}{*}{ Liquid ratio } & $5.33713^{\star \star \star}$ & $1.42019^{* \star \star}$ & $1.77920^{\star \star \star}$ & $7.13189^{\star \star \star}$ & -0.21343 & $2.19049^{\star \star \star}$ \\
\hline & $(20.80)$ & $(2.87)$ & $(6.61)$ & $(23.11)$ & $(0.26)$ & $(7.62)$ \\
\hline \multirow{2}{*}{ Loss reserve to total lending ratio } & $0.17275^{\star \star \star}$ & $-0.25029^{\star \star \star}$ & $0.05006^{* \star}$ & $0.08386^{\star \star \star}$ & -0.05653 & $0.05175^{\star \star}$ \\
\hline & $(7.11)$ & $(2.98)$ & $(2.43)$ & $(2.98)$ & $(0.44)$ & $(2.45)$ \\
\hline \multirow{2}{*}{ Total assets growth rate } & $0.01306^{* * *}$ & $0.01269^{\star \star \star}$ & $0.01701^{\star \star \star}$ & $0.01163^{\star \star \star}$ & $0.00611^{* \star *}$ & $0.01716^{\star * \star}$ \\
\hline & $(17.23)$ & $(17.86)$ & $(13.84)$ & $(20.21)$ & $(8.12)$ & $(13.66)$ \\
\hline \multirow{2}{*}{ Lending to deposit ratio } & $-0.00574^{\star \star \star}$ & $-0.03142^{\star \star \star}$ & $-0.00210^{\star \star \star}$ & $-0.00452^{\star \star \star}$ & $-0.04210^{\star \star \star}$ & $-0.00208^{* *}$ \\
\hline & $(7.65)$ & $(14.36)$ & $(3.28)$ & $(5.10)$ & (11.49) & $(3.19)$ \\
\hline \multirow{2}{*}{ Credit-to-collateralized lending ratio } & $-0.00072^{\star \star \star}$ & 0.02709 & $-0.00064^{*}$ & -0.00031 & -0.11461 & -0.00050 \\
\hline & $(2.68)$ & $(0.29)$ & $(1.76)$ & $(0.96)$ & $(0.73)$ & $(1.36)$ \\
\hline \multirow{2}{*}{ Average monthly MKT share } & $0.10812^{* \star *}$ & $0.18975^{\star \star \star}$ & $-0.25218^{\star \star \star}$ & & & \\
\hline & $(3.95)$ & $(3.87)$ & $(7.18)$ & & & \\
\hline \multirow{2}{*}{ Bank branch MKT share } & & & & $0.53610^{\star \star \star}$ & $0.50941^{\star \star \star}$ & -0.04771 \\
\hline & & & & $(16.23)$ & $(5.41)$ & $(1.49)$ \\
\hline Observations & 4947 & 2214 & 2733 & 4524 & 1763 & 2761 \\
\hline Number of Banks & 32 & 29 & 32 & 32 & 29 & 32 \\
\hline R-squared & 0.29187 & 0.62342 & 0.29645 & 0.45581 & 0.69793 & 0.28113 \\
\hline
\end{tabular}

Notes: Average monthly deposit and branch market shares are used as the explanatory variables of interest. The regression model uses fundamental bank information, excluding macroeconomic and lending practice information. Absolute value of $t$ statistics in parentheses* significant at $10 \%$; $*$ significantat $5 \% ; * *$ significant at $1 \%$. 
Table 3 shows that the overall effect of the loanloss reserve to total lending ratio is positive and significant. However, in subsamples, the effects are positive between 2001 and 2009 and negative between 1991 and 2000. The lending to deposit ratio is the total lending to the total deposit ratio. The lending to deposit ratio has the same effect on the bank lending practices as the debt-to-asset ratio. If a bank's deposits are low compared to what the bank has lent out, then a bank would be forced to engage in more prudent lending practices, avoiding higher risk borrowers. Table 3 shows that the lending to deposit ratio has a negative and significant effect on NIMs, indicating that banks with higher ratios make loans at lower NIMs across all periods.

Table 4. Deposit and branch market shares - adding macroeconomic information

\begin{tabular}{|c|c|c|c|c|c|c|}
\hline & \multicolumn{3}{|c|}{ Average monthly deposit market share } & \multicolumn{3}{|c|}{ Bank branch market share } \\
\hline & All & $1991 \sim 2000$ & 2001 2009 & All & $1991 \sim 2000$ & 2001 2009 \\
\hline \multirow{2}{*}{ Debt-to-asset ratio } & $-0.04030^{\star \star \star}$ & $-0.03870^{\star \star \star}$ & $-0.06353^{\star \star *}$ & $-0.05996^{\star \star \star}$ & $-0.06785^{\star \star \star}$ & $-0.07091^{\star \star \star}$ \\
\hline & $(8.19)$ & $(5.54)$ & $(9.76)$ & $(9.66)$ & $(5.16)$ & $(10.74)$ \\
\hline \multirow{2}{*}{ NPL percentage } & $0.05840^{\star \star \star}$ & $0.03055^{\star}$ & $0.13299^{\star \star \star}$ & $0.08685^{\star \star \star}$ & $0.05954^{\star \star \star}$ & $0.13684^{\star \star \star}$ \\
\hline & (6.33) & $(1.82)$ & (13.34) & $(9.25)$ & $(3.14)$ & $(13.70)$ \\
\hline \multirow{2}{*}{ Service interest to total income ratio } & $3.88882^{\star \star \star}$ & $12.07762^{\star \star \star}$ & $1.22730^{\star \star \star}$ & $3.53967^{\star \star \star}$ & $14.33368^{\star \star *}$ & $1.16710^{* *}$ \\
\hline & $(7.50)$ & $(8.83)$ & $(2.60)$ & $(6.83)$ & $(10.59)$ & $(2.43)$ \\
\hline \multirow{2}{*}{ Administrative cost percentage } & $0.03024^{\star \star \star}$ & $0.15156^{\star \star \star}$ & $-0.02740^{\star \star \star}$ & $0.01127^{\star \star \star}$ & $0.16136^{\star \star \star}$ & $-0.02671^{\star \star *}$ \\
\hline & $(8.60)$ & $(21.28)$ & $(7.42)$ & $(3.14)$ & $(19.26)$ & $(7.11)$ \\
\hline \multirow{2}{*}{ Discount rates } & $-0.08349^{* \star \star}$ & $0.21138^{\star \star}$ & $-0.05050^{\star \star}$ & $0.04239^{*}$ & $0.26551^{* \star}$ & -0.03941 \\
\hline & (3.70) & $(2.31)$ & $(1.98)$ & $(1.76)$ & $(2.50)$ & $(1.51)$ \\
\hline \multirow{2}{*}{ Base lending rate } & $0.11540^{\star \star \star}$ & 0.15396 & $-0.07554^{\star \star *}$ & $0.07552^{\star \star \star}$ & $0.33024^{\star \star \star}$ & $-0.06835^{\star \star \star}$ \\
\hline & $(6.27)$ & $(1.61)$ & $(4.34)$ & $(4.19)$ & $(2.79)$ & $(3.86)$ \\
\hline \multirow{2}{*}{ Liquid ratio } & $5.15146^{\star \star \star}$ & $1.55733^{\star \star \star}$ & $1.84433^{\star \star \star}$ & $5.93222^{\star \star \star}$ & $1.13674^{*}$ & $2.30483^{\star \star \star}$ \\
\hline & $(18.56)$ & $(2.77)$ & $(6.47)$ & (20.73) & $(1.86)$ & $(7.79)$ \\
\hline \multirow{2}{*}{ Loss reserve to total lending } & $0.15884^{\star \star \star}$ & $-0.29814^{\star \star \star}$ & $0.03983^{*}$ & $0.12539^{\star \star \star}$ & $-0.15460^{*}$ & $0.03776^{*}$ \\
\hline & (6.60) & $(3.56)$ & (1.91) & $(5.35)$ & $(1.87)$ & $(1.78)$ \\
\hline \multirow{2}{*}{ Total assets growth rate } & $0.00973^{\star \star \star}$ & $0.01286^{\star \star \star}$ & $0.01553^{\star \star \star}$ & $0.00341^{\star \star \star}$ & -0.00052 & $0.01537^{\star \star \star}$ \\
\hline & $(10.15)$ & $(11.20)$ & (12.39) & $(2.77)$ & $(0.27)$ & (12.03) \\
\hline \multirow{2}{*}{ Lending to deposit ratio } & $-0.00519^{\star \star \star}$ & $-0.02972^{\star \star \star}$ & $-0.00236^{\star \star \star}$ & $-0.00410^{\star \star \star}$ & $-0.03435^{\star \star \star}$ & $-0.00243^{\star \star \star}$ \\
\hline & (6.91) & (12.62) & $(3.69)$ & $(5.49)$ & (13.59) & $(3.74)$ \\
\hline \multirow{2}{*}{ Credit-to-collateralized lending } & $-0.00078^{\star \star \star}$ & -0.09523 & $-0.00063^{*}$ & -0.00044 & 0.06189 & -0.00049 \\
\hline & (2.92) & $(1.03)$ & $(1.75)$ & $(1.64)$ & $(0.59)$ & $(1.33)$ \\
\hline \multirow{2}{*}{ Bank assets to GDP ratio } & $-20.79080^{\star \star \star}$ & $-29.56286^{\star \star *}$ & $10.54492^{\star * \star}$ & $11.06077^{\star \star \star}$ & $10.15738^{*}$ & $11.57668^{\star \star \star}$ \\
\hline & $(8.47)$ & $(9.26)$ & $(3.07)$ & $(3.19)$ & $(1.87)$ & $(3.31)$ \\
\hline \multirow{2}{*}{ GDP growth rate } & $-0.01890^{\star \star \star}$ & $-0.05628^{\star \star \star}$ & $0.01198^{\star \star \star}$ & 0.00385 & -0.01886 & $0.01177^{\star \star \star}$ \\
\hline & $(4.00)$ & $(4.12)$ & $(2.78)$ & $(0.79)$ & $(1.30)$ & $(2.68)$ \\
\hline \multirow{2}{*}{ Stock capitalization to GDP ratio } & $-0.08756^{\star \star \star}$ & $0.64845^{\star \star \star}$ & $-0.02012^{*}$ & $-0.09836^{\star \star \star}$ & $1.11856^{\star \star \star}$ & $-0.02891^{\star \star}$ \\
\hline & (6.46) & $(2.66)$ & $(1.80)$ & $(7.37)$ & $(4.49)$ & $(2.52)$ \\
\hline \multirow{2}{*}{ Monthly total assets } & $0.36699^{* \star \star}$ & $0.93384^{\star \star \star}$ & 0.33883 & $0.27287^{\star \star}$ & -0.05567 & $0.58025^{\star \star \star}$ \\
\hline & $(3.80)$ & $(5.78)$ & $(1.56)$ & $(2.43)$ & $(0.26)$ & $(2.62)$ \\
\hline \multirow{2}{*}{ Average monthly MKT share } & $0.10014^{* * *}$ & $0.11480^{\star \star}$ & $-0.23911^{\star \star *}$ & & & \\
\hline & (3.65) & (2.33) & (6.72) & & & \\
\hline \multirow{2}{*}{ Bank branch MKT share } & & & & $0.40110^{\star \star \star}$ & -0.035820 & -0.047369 \\
\hline & & & & (14.36) & $(0.47)$ & $(1.42)$ \\
\hline Observations & 4922 & 2189 & 2733 & 4507 & 1746 & 2761 \\
\hline Number of Banks & 32 & 29 & 32 & 32 & 29 & 32 \\
\hline R-squared & 0.28840 & 0.61266 & 0.30484 & 0.25143 & 0.36631 & 0.29347 \\
\hline
\end{tabular}

Notes: Average monthly deposit and branch market shares are used as the explanatory variables of interest. The regression model uses fundamental bank information, lending practice and macroeconomic information. Absolute value of $t$ statistics in parentheses* significant at $10 \%$; ** significantat $5 \%$; *** significant at $1 \%$.

Table 4 includes additional variables based on macroeconomic data. For the third model specification, we incorporate the total bank assets as an indicator of market structure and scale effects. The total bank assets to GDP ratio is a proxy for the banking industry's power in the country. In the panel regression analysis, we get positive and significant results for all samples except for monthly average deposit market share from 1991 to 2000 . 
The average monthly deposit market share yields significant results consistent with the previous two model specifications, and the branch market share's aggregate sample result is significant and consistent as well. However, the subsamples' results are insignificant in this model specification.

The deposit market shares and branch market shares overall are positively correlated with banks' NIMs before 2000. But the coefficients are negative between 2001-2009. During 2001-2009, collateralized lending became less profitable for banks due to the increasing competition.

\section{Credit lending and collateralized lending market shares}

We include credit lending market share and collateralized lending market share. We conduct panel regression analyses based on the previous three model specifications to determine whether the regressions yield consistent results. Since credit lending market share and collateralized market share are explanatory variables, the credit lending to collateralized lending ratio is excluded from the variable list.

Table 5. Credit lending and collateralized lending market shares - base model

\begin{tabular}{|c|c|c|c|c|c|c|}
\hline & \multicolumn{3}{|c|}{ Credit lending } & \multicolumn{3}{|c|}{ Collateralized lending } \\
\hline & All & $1991 \sim 2000$ & 2001 2009 & All & $1991 \sim 2000$ & 2001 2009 \\
\hline \multirow{2}{*}{ Debt-to-asset ratio } & $-0.12560^{* * *}$ & $-0.18245^{* * *}$ & $-0.01779^{* * *}$ & $-0.12448^{\star \star \star}$ & $-0.18370^{\star * *}$ & $-0.01844^{\star \star *}$ \\
\hline & (32.39) & (32.78) & $(4.61)$ & (32.16) & (33.43) & $(4.75)$ \\
\hline \multirow{2}{*}{ NPL percentage } & $0.10167^{\star \star \star}$ & -0.00916 & $0.12463^{\star \star \star}$ & $0.09650^{\star \star \star}$ & 0.01099 & $0.11910^{\star \star \star}$ \\
\hline & $(7.37)$ & $(0.37)$ & $(13.23)$ & $(7.03)$ & $(0.45)$ & $(12.60)$ \\
\hline \multirow{2}{*}{ Service interest to total income ratio } & $12.80739^{\star \star *}$ & $33.15070^{\star \star \star}$ & $1.54377^{\star \star \star}$ & $12.96833^{\star \star \star}$ & $33.46166^{\star \star \star}$ & $1.34533^{\star \star \star}$ \\
\hline & $(20.72)$ & $(37.72)$ & $(3.42)$ & $(20.99)$ & $(38.34)$ & $(2.98)$ \\
\hline \multirow{2}{*}{ Administrative cost percentage } & 0.00636 & $0.05634^{\star \star \star}$ & $-0.02513^{\star \star \star}$ & 0.00670 & $0.06152^{\star \star \star}$ & $-0.02702^{\star \star \star}$ \\
\hline & $(1.28)$ & $(6.01)$ & $(6.90)$ & $(1.35)$ & $(6.55)$ & $(7.44)$ \\
\hline \multirow{2}{*}{ Discount rates } & $0.08606^{\star \star \star}$ & $-0.48621^{\star \star \star}$ & $-0.16855^{\star \star \star}$ & $0.08742^{\star \star \star}$ & $-0.46846^{\star \star \star}$ & $-0.17106^{\star \star \star}$ \\
\hline & $(2.95)$ & $(5.09)$ & $(7.23)$ & $(2.99)$ & $(4.95)$ & $(7.28)$ \\
\hline \multirow{2}{*}{ Base lending rate } & 0.02408 & -0.05262 & $-0.06029^{\star \star \star}$ & 0.03150 & -0.10843 & $-0.06231^{\star \star *}$ \\
\hline & $(0.92)$ & $(0.35)$ & $(3.81)$ & $(1.21)$ & $(0.74)$ & $(3.90)$ \\
\hline \multirow{2}{*}{ Liquid ratio } & $6.66927^{\star \star \star}$ & $6.29387^{\star \star \star}$ & $1.97553^{\star \star \star}$ & $6.75137^{\star \star \star}$ & $6.13639^{\star \star \star}$ & $1.76519^{\star \star \star}$ \\
\hline & $(17.84)$ & $(8.32)$ & $(7.51)$ & (18.06) & $(8.16)$ & $(6.62)$ \\
\hline \multirow{2}{*}{ Mkt share of credit lending } & $5.42561^{\star \star \star}$ & $3.65599^{\star \star \star}$ & $6.54808^{\star \star \star}$ & & & \\
\hline & $(7.12)$ & $(4.59)$ & $(4.55)$ & & & \\
\hline \multirow{2}{*}{ Collateralized lending Mkt share } & & & & $4.05908^{\star \star \star}$ & $4.73289^{\star \star \star}$ & 0.17938 \\
\hline & & & & (6.13) & $(6.72)$ & $(0.14)$ \\
\hline Observations & 5230 & 2322 & 2908 & 5230 & 2322 & 2908 \\
\hline Number of banks & 34 & 31 & 34 & 34 & 31 & 34 \\
\hline R-squared & 0.37784 & 0.70559 & 0.19732 & 0.37627 & 0.70863 & 0.19153 \\
\hline
\end{tabular}

Note: Monthly credit lending market share and collateralized lending market share are used as the explanatory variables of interest. The regression model uses fundamental bank information, excluding macroeconomic and lending practice information. Absolute value of $t$ statistics in parentheses* significant at $10 \%$; ** significantat 5\%; *** significant at $1 \%$.

The market shares of credit lending and collateralized lending are important factors that affectthe NIMs. First, the credit lending market share is highly significant in affecting the level of NIMs, and its effect is stronger for the second sub-period. As discussed earlier, the lending practice shifted from collateralized to credit lending, and the results here indicate this shift as well. The collateralized lending market share, on the other hand, has significant impacts between 1999 and 2000, but it loses its significance from 2001 to 2009. This implies that the Taiwanese banks strayed away from safer lending practices (making loans based on collateral) and let the profitability be driven by credit loans.

Table 6. Credit lending and collateralized lending market shares - adding macroeconomic information

\begin{tabular}{|c|c|c|c|c|c|c|}
\hline & \multicolumn{3}{|c|}{ Credit lending } & \multicolumn{3}{|c|}{ Collateralized lending } \\
\hline & All & $1991 \sim 2000$ & $2001 \sim 2009$ & All & $1991 \sim 2000$ & 2001 2009 \\
\hline \multirow{2}{*}{ Debt-to-asset ratio } & $-0.04527^{\star \star \star}$ & $-0.02947^{\star * \star}$ & $-0.06678^{* * *}$ & $-0.04413^{* \star *}$ & $-0.03374^{* * *}$ & $-0.06564^{* \star *}$ \\
\hline & $(9.07)$ & $(4.47)$ & $(10.28)$ & $(8.90)$ & $(5.13)$ & $(10.04)$ \\
\hline \multirow{2}{*}{ NPL percentage } & $0.06796^{\star \star \star}$ & 0.00253 & $0.13606^{\star \star \star}$ & $0.06397^{\star \star \star}$ & 0.00899 & $0.13072^{\star \star *}$ \\
\hline & (7.39) & $(0.16)$ & $(13.98)$ & $(7.01)$ & $(0.57)$ & $(13.30)$ \\
\hline \multirow{2}{*}{ Service interest to total income } & $3.58904^{\star \star \star}$ & $8.06275^{\star \star \star}$ & $1.48868^{* \star \star}$ & $3.74984^{\star \star \star}$ & $8.24047^{\star \star \star}$ & $1.12515^{\star \star}$ \\
\hline & $(7.20)$ & $(6.85)$ & (3.23) & $(7.54)$ & $(7.03)$ & $(2.44)$ \\
\hline
\end{tabular}


Table 6 (cont.). Credit lending and collateralized lending market shares - adding macroeconomic information

\begin{tabular}{|c|c|c|c|c|c|c|}
\hline & \multicolumn{3}{|c|}{ Credit lending } & \multicolumn{3}{|c|}{ Collateralized lending } \\
\hline & All & $1991 \sim 2000$ & 2001 2009 & All & $1991 \sim 2000$ & $2001 \sim 2009$ \\
\hline \multirow{2}{*}{ Administrative cost percentage } & $0.03093^{\star \star \star}$ & $0.15013^{\star \star \star}$ & $-0.02275^{\star \star \star}$ & $0.02988^{* \star *}$ & $0.15683^{\star \star *}$ & $-0.02423^{\star * \star}$ \\
\hline & $(8.84)$ & $(20.95)$ & (6.15) & $(8.57)$ & $(21.86)$ & $(6.53)$ \\
\hline \multirow{2}{*}{ Discount rates } & -0.03138 & $0.21714^{\star *}$ & -0.03018 & $-0.04229^{*}$ & $0.17807^{\star \star}$ & -0.03127 \\
\hline & $(1.36)$ & $(2.39)$ & $(1.17)$ & $(1.87)$ & $(1.97)$ & $(1.21)$ \\
\hline \multirow{2}{*}{ Base lending rate } & $0.10636^{\star \star \star}$ & $0.17348^{*}$ & $-0.05879^{\star \star \star}$ & $0.10733^{\star \star \star}$ & 0.14994 & $-0.06584^{\star \star \star}$ \\
\hline & $(5.78)$ & $(1.86)$ & $(3.34)$ & $(5.83)$ & $(1.61)$ & $(3.71)$ \\
\hline \multirow{2}{*}{ Liquid ratio } & $5.81027^{\star \star \star}$ & $2.08095^{\star \star \star}$ & $2.78083^{\star \star *}$ & $5.78300^{\star \star \star}$ & $1.78543^{\star \star \star}$ & $2.41221^{* \star *}$ \\
\hline & $(20.97)$ & $(3.76)$ & $(9.63)$ & $(20.90)$ & $(3.22)$ & $(8.32)$ \\
\hline \multirow{2}{*}{ Loss reserve to total lending } & $0.15232^{\star \star \star}$ & $-0.30219^{\star \star \star}$ & $0.05151^{\star \star}$ & $0.15887^{\star \star \star}$ & $-0.27804^{\star \star *}$ & $0.04989^{\star *}$ \\
\hline & $(6.31)$ & $(3.64)$ & $(2.45)$ & $(6.58)$ & $(3.34)$ & $(2.36)$ \\
\hline \multirow{2}{*}{ Total assets growth rate } & $0.01048^{\star \star \star}$ & $0.01167^{\star \star \star}$ & $0.01481^{\star \star \star}$ & $0.01022^{\star \star \star}$ & $0.01304^{* \star \star}$ & $0.01603^{\star \star \star}$ \\
\hline & $(10.81)$ & $(9.87)$ & $(11.64)$ & $(10.58)$ & $(11.19)$ & $(12.47)$ \\
\hline \multirow{2}{*}{ Lending to deposit ratio } & $-0.00573^{\star \star \star}$ & $-0.02843^{\star \star \star}$ & $-0.00254^{* \star \star}$ & $-0.00559^{\star \star \star}$ & $-0.02953^{\star \star *}$ & $-0.00239^{* * *}$ \\
\hline & $(7.59)$ & $(12.17)$ & $(3.92)$ & $(7.40)$ & $(12.58)$ & $(3.67)$ \\
\hline \multirow{2}{*}{ Bank assets to GDP ratio } & $-15.76297^{\star \star \star}$ & $-35.38536^{\star \star \star}$ & $14.04391^{* \star *}$ & $-17.54651^{\star \star \star}$ & $-27.84597^{\star \star \star}$ & $13.30336^{\star \star \star}$ \\
\hline & $(5.95)$ & $(10.19)$ & $(4.11)$ & $(6.85)$ & $(8.27)$ & $(3.87)$ \\
\hline \multirow{2}{*}{ GDP growth rate } & $-0.01376^{* \star *}$ & $-0.06601^{* \star *}$ & $0.01471^{\star \star \star}$ & $-0.01525^{\star \star \star}$ & $-0.05344^{\star \star \star}$ & $0.01384^{\star \star \star}$ \\
\hline & $(2.88)$ & $(4.84)$ & $(3.42)$ & $(3.21)$ & $(3.95)$ & $(3.20)$ \\
\hline \multirow{2}{*}{ Stock capitalization to GDP ratio } & $-0.09349^{* \star *}$ & $0.79136^{\star \star *}$ & $-0.04606^{\star * *}$ & $-0.09384^{* \star *}$ & $0.78051^{* * *}$ & $-0.04095^{\star \star \star}$ \\
\hline & $(7.03)$ & $(3.25)$ & $(4.15)$ & $(7.05)$ & $(3.21)$ & $(3.68)$ \\
\hline \multirow{2}{*}{ Monthly total assets } & $0.56520^{\star \star \star}$ & $1.04400^{\star \star \star}$ & $0.42608^{\star \star}$ & $0.55240^{\star \star \star}$ & $1.05445^{\star \star \star}$ & 0.34439 \\
\hline & $(5.89)$ & $(6.60)$ & $(2.01)$ & $(5.77)$ & $(6.69)$ & $(1.62)$ \\
\hline \multirow{2}{*}{ Mkt share of credit lending } & $4.45871^{\star \star \star}$ & $-1.32599^{*}$ & $7.60108^{\star \star \star}$ & & & \\
\hline & $(6.32)$ & $(1.78)$ & $(5.48)$ & & & \\
\hline \multirow{2}{*}{ Collateralized lending Mkt share } & & & & $3.25418^{* * *}$ & $1.93268^{\star \star *}$ & -1.10599 \\
\hline & & & & $(6.06)$ & (3.61) & $(0.87)$ \\
\hline Observations & 5092 & 2241 & 2851 & 5092 & 2241 & 2851 \\
\hline Number of Banks & 32 & 29 & 32 & 32 & 29 & 32 \\
\hline R-squared & 0.29121 & 0.60319 & 0.30638 & 0.29077 & 0.60496 & 0.29915 \\
\hline
\end{tabular}

Note: Monthly credit lending market share and collateralized lending market share are used as the explanatory variables of interest. The regression model uses fundamental bank information, lending practice information and macroeconomic information. Absolute value of $t$ statistics in parentheses* significant at $10 \%$; ** significantat $5 \% ; * * *$ significant at $1 \%$.

Table 6 is based on the third model specification, and it shows consistent results.

Based on the above results, collateralized lending market shares do not drive up NIMs during 20012009. After 2001, credit lending becomes more crucial for banks' profitability, and if a bank can produce popular credit cards or cash cards (small credit loans), their popularity may drive up demand for loans and raise the bank's NIMs.

\section{Market concentration}

Different NIMs and types of market concentration are examined. The market concentrations used in this paper are Herfindahl indices, calculated as the sum of squared market shares of each bank.

Table 7. Herfindahls based on bank deposits and branches - adding macroeconomic information

\begin{tabular}{|c|c|c|c|c|c|c|}
\hline & \multicolumn{3}{|c|}{ Herfindahl based on bank deposits } & \multicolumn{3}{|c|}{ Herfindahl based on bank branches } \\
\hline & All & $1991 \sim 2000$ & 2001 2009 & All & $1991 \sim 2000$ & 2001 2009 \\
\hline \multirow{2}{*}{ Debt-to-asset ratio } & $-0.03778^{\star \star \star}$ & $-0.02580^{\star \star \star}$ & $-0.05966^{\star \star \star}$ & $-0.03426^{\star \star *}$ & $-0.03621^{\star \star \star}$ & $-0.05906^{* \star *}$ \\
\hline & (7.72) & (3.81) & (9.11) & (6.93) & $(5.48)$ & $(9.10)$ \\
\hline \multirow{2}{*}{ NPL percentage } & $0.05887^{\star \star \star}$ & 0.01423 & $0.13520^{* * *}$ & $0.05955^{\star \star \star}$ & 0.01010 & $0.13680^{\star * \star}$ \\
\hline & $(6.32)$ & $(0.90)$ & $(13.74)$ & $(6.45)$ & $(0.63)$ & $(14.00)$ \\
\hline \multirow{2}{*}{ Service interest to total income } & $4.13089^{\star \star *}$ & $10.95732^{* \star *}$ & $1.35435^{\star * *}$ & $3.96478^{* \star *}$ & $12.15072^{* * *}$ & $1.13212^{\star *}$ \\
\hline & $(7.89)$ & $(7.93)$ & (2.83) & $(7.56)$ & $(8.90)$ & (2.38) \\
\hline \multirow{2}{*}{ Administrative cost percentage } & $0.02704^{\star \star \star}$ & $0.15423^{\star \star *}$ & $-0.02413^{\star \star \star}$ & $0.02709^{\star \star \star}$ & $0.15302^{* \star \star}$ & $-0.02447^{\star \star \star}$ \\
\hline & $(7.67)$ & $(21.60)$ & $(6.50)$ & $(7.72)$ & (21.45) & $(6.64)$ \\
\hline
\end{tabular}


Table 7 (cont.). Herfindahls based on bank deposits and branches - adding macroeconomic information

\begin{tabular}{|c|c|c|c|c|c|c|}
\hline & \multicolumn{3}{|c|}{ Herfindahl based on bank deposits } & \multicolumn{3}{|c|}{ Herfindahl based on bank branches } \\
\hline & All & $1991 \sim 2000$ & 2001 2009 & All & $1991 \sim 2000$ & 2001 2009 \\
\hline \multirow{2}{*}{ Discount rates } & $-0.06664^{\star \star *}$ & 0.12942 & -0.02898 & $-0.04549^{* *}$ & 0.10401 & $-0.04444^{*}$ \\
\hline & $(2.94)$ & $(1.40)$ & $(1.12)$ & $(1.96)$ & $(1.09)$ & $(1.73)$ \\
\hline \multirow{2}{*}{ Base lending rate } & $0.09712^{\star \star \star}$ & $0.27398^{\star * *}$ & $-0.05944^{* * *}$ & $0.08879^{\star \star *}$ & $0.37761^{* * *}$ & -0.00633 \\
\hline & $(5.17)$ & $(2.80)$ & $(3.38)$ & $(4.78)$ & (3.34) & $(0.34)$ \\
\hline \multirow{2}{*}{ Liquid ratio } & $5.54071^{\star * *}$ & $1.64172^{\star * \star}$ & $1.92084^{* * *}$ & $5.43984^{* \star *}$ & $1.61177^{\star \star *}$ & $1.82978^{* * *}$ \\
\hline & $(19.90)$ & $(2.96)$ & $(6.55)$ & $(19.57)$ & $(2.89)$ & $(6.33)$ \\
\hline \multirow{2}{*}{ Loss reserve to total lending } & $0.15455^{\star \star \star}$ & $-0.27549^{\star \star \star}$ & $0.05581^{\star \star \star}$ & $0.15532^{\star \star \star}$ & $-0.31947^{\star \star \star}$ & $0.05496^{\star \star \star}$ \\
\hline & $(6.36)$ & $(3.29)$ & $(2.65)$ & $(6.41)$ & $(3.84)$ & $(2.63)$ \\
\hline \multirow{2}{*}{ Total assets growth rate } & $0.00953^{* * *}$ & $0.01335^{\star * *}$ & $0.01373^{\star * *}$ & $0.00957^{\star \star \star}$ & $0.01238^{\star \star *}$ & $0.01355^{* * *}$ \\
\hline & $(9.84)$ & $(11.57)$ & (10.62) & (9.91) & $(10.80)$ & $(10.63)$ \\
\hline \multirow{2}{*}{ Lending to deposit ratio } & $-0.00566^{* \star *}$ & $-0.02897^{\star * \star}$ & $-0.00216^{\star \star *}$ & $-0.00573^{\star * \star}$ & $-0.02886^{* * *}$ & $-0.00215^{\star \star \star}$ \\
\hline & $(7.45)$ & $(12.39)$ & $(3.33)$ & $(7.56)$ & $(12.31)$ & $(3.34)$ \\
\hline \multirow{2}{*}{ Credit-to-collateralized lending } & $-0.00094^{\star \star \star}$ & $-0.21486^{\star *}$ & -0.00044 & $-0.00093^{\star \star \star}$ & -0.11098 & -0.00047 \\
\hline & (3.55) & $(2.28)$ & $(1.20)$ & $(3.52)$ & $(1.21)$ & $(1.28)$ \\
\hline \multirow{2}{*}{ Bank assets to GDP ratio } & $-21.83327^{\star * *}$ & $-40.23366^{* \star *}$ & 4.97412 & $-23.95032^{* \star *}$ & $-24.22385^{* * *}$ & 0.23261 \\
\hline & $(8.19)$ & $(10.15)$ & $(1.35)$ & $(9.45)$ & $(6.61)$ & $(0.06)$ \\
\hline \multirow{2}{*}{ GDP growth rate } & $-0.01923^{* * *}$ & $-0.05270^{\star * *}$ & $0.01253^{* * *}$ & $-0.01670^{* * *}$ & $-0.06393^{\star * *}$ & 0.00607 \\
\hline & $(4.00)$ & $(3.86)$ & $(2.88)$ & $(3.48)$ & $(4.66)$ & $(1.38)$ \\
\hline \multirow{2}{*}{ Stock capitalization to GDP ratio } & $-0.09020^{* \star \star}$ & $0.66033^{\star \star \star}$ & -0.00448 & $-0.07861^{* \star \star}$ & $1.03643^{\star \star \star}$ & 0.00786 \\
\hline & $(6.27)$ & $(2.72)$ & $(0.36)$ & $(5.72)$ & $(3.89)$ & $(0.64)$ \\
\hline \multirow{2}{*}{ Monthly total assets } & $0.40050^{* * *}$ & $1.13940^{* * *}$ & $2.03419^{* \star *}$ & $0.69262^{* \star *}$ & $0.52280^{* *}$ & $3.22142^{* * *}$ \\
\hline & $(4.09)$ & $(6.78)$ & $(6.05)$ & $(5.86)$ & $(2.56)$ & $(8.36)$ \\
\hline \multirow{2}{*}{ Deposit Herfindahl } & 2.83207 & $33.00630^{* * *}$ & $-132.58194^{* \star \star}$ & & & \\
\hline & $(0.41)$ & $(4.14)$ & $(6.21)$ & & & \\
\hline \multirow{2}{*}{ Branch Herfindahl } & & & & $-14.93339^{\star \star \star}$ & $12.34532^{\star \star \star}$ & $-88.90192^{\star \star \star}$ \\
\hline & & & & $(4.26)$ & (3.32) & $(8.69)$ \\
\hline Observations & 4984 & 2191 & 2793 & 4984 & 2191 & 2793 \\
\hline Number of Banks & 32 & 29 & 32 & 32 & 29 & 32 \\
\hline R-squared & 0.28837 & 0.61506 & 0.30332 & 0.29096 & 0.61398 & 0.31247 \\
\hline
\end{tabular}

Note: Average monthly deposit and branch market shares are used as the explanatory variables of interest. The regression model uses fundamental bank information, lending practice and macroeconomic information. Absolute value of $t$ statistics in parentheses * significant at $10 \%$; ** significant at $5 \%$; *** significant at $1 \%$.

Herfindahl indices for credit lending and colla- such that higher market concentrations lead to teralized lending provide consistent results. Both higher NIMs. But this effect disappeared during types of Herfindahl indices indicate that for the 2001 to 2009 such that higher market overall period and the first period (1991-2000), concentration for both types of lending leads to there is evidence of collusion based on the data lower NIMs.

Table 8 . Herfindahls based on credit lending and collateralized lending - base model

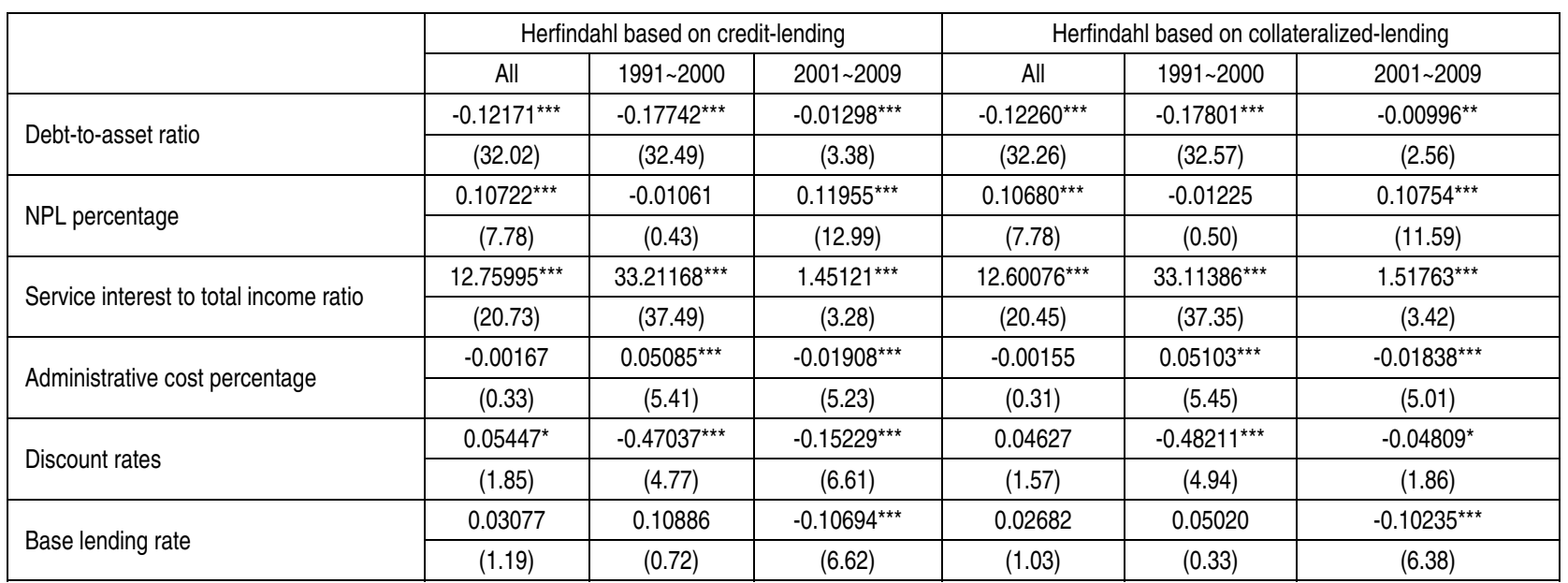


Table 8 (cont.). Herfindahls based on credit lending and collateralized lending - base model

\begin{tabular}{|c|c|c|c|c|c|c|}
\hline & \multicolumn{3}{|c|}{ Herfindahl based on credit-lending } & \multicolumn{3}{|c|}{ Herfindahl based on collateralized-lending } \\
\hline & All & $1991 \sim 2000$ & 2001 2009 & All & $1991 \sim 2000$ & 2001 2009 \\
\hline \multirow{2}{*}{ Liquid ratio } & $6.38434^{* \star *}$ & $6.55204^{\star \star \star}$ & $0.99594^{\star * *}$ & $6.41490^{\star \star \star}$ & $6.44708^{\star \star \star}$ & $0.87874^{\star \star *}$ \\
\hline & $(16.99)$ & $(8.59)$ & $(3.76)$ & $(17.14)$ & $(8.45)$ & $(3.27)$ \\
\hline \multirow{2}{*}{ Credit-lending Herfindahl } & $6.29515^{\star \star \star}$ & 1.30249 & $-22.03993^{\star \star \star}$ & & & \\
\hline & $(8.65)$ & $(1.58)$ & $(10.39)$ & & & \\
\hline \multirow{2}{*}{ Collateralized-lending Herfindahl } & & & & $4.97988^{\star \star \star}$ & $1.33060^{\star *}$ & $-21.88726^{\star \star \star}$ \\
\hline & & & & $(9.36)$ & $(2.27)$ & $(10.31)$ \\
\hline Observations & 5242 & 2334 & 2908 & 5242 & 2334 & 2908 \\
\hline Number of Banks & 34 & 31 & 34 & 34 & 31 & 34 \\
\hline R-squared & 0.38078 & 0.70322 & 0.22084 & 0.38227 & 0.70356 & 0.22043 \\
\hline
\end{tabular}

Note: Monthly credit lending market share and collateralized lending market share are used as the explanatory variables of interest. The regression model uses fundamental bank information, excluding macroeconomic and lending practice information. Absolute value of $t$ statistics in parentheses * significant at $10 \%$; ** significant at $5 \%$; *** significant at $1 \%$.

Table 9. Herfindahls based on credit lending and collateralized lending - adding lending practice information

\begin{tabular}{|c|c|c|c|c|c|c|}
\hline & \multicolumn{3}{|c|}{ Herfindahl based on credit-lending } & \multicolumn{3}{|c|}{ Herfindahl based on collateralized-lending } \\
\hline & All & 1991 2000 & 2001 2009 & All & 1991 2000 & 2001 2009 \\
\hline \multirow{2}{*}{ Debt-to-asset ratio } & $-0.17571^{\star \star \star}$ & $-0.17422^{\star \star \star}$ & $-0.05643^{* \star *}$ & $-0.17612^{\star \star \star}$ & $-0.17455^{\star \star \star}$ & $-0.05344^{\star \star \star}$ \\
\hline & $(45.24)$ & (33.38) & $(9.04)$ & (45.46) & (33.39) & (8.30) \\
\hline \multirow{2}{*}{ NPL percentage } & $0.10618^{\star \star \star}$ & $0.06996^{\star \star \star}$ & $0.12360^{\star \star \star}$ & $0.10881^{\star \star \star}$ & $0.06798^{\star \star \star}$ & $0.11791^{\star \star \star}$ \\
\hline & $(8.37)$ & $(2.82)$ & $(13.17)$ & $(8.63)$ & $(2.77)$ & $(12.40)$ \\
\hline \multirow{2}{*}{ Service interest to total income ratio } & $17.45906^{* * *}$ & $31.17732^{* \star *}$ & $1.55065^{\star \star \star}$ & $17.30645^{\star \star \star}$ & $31.12799^{* * *}$ & $1.52768^{\star \star \star}$ \\
\hline & $(30.20)$ & $(35.96)$ & (3.23) & (29.92) & $(35.87)$ & (3.19) \\
\hline \multirow{2}{*}{ Administrative cost percentage } & $-0.00836^{*}$ & $0.05134^{* \star \star}$ & $-0.02207^{\star \star \star}$ & $-0.00901^{*}$ & $0.05164^{\star \star \star}$ & $-0.02132^{\star \star \star}$ \\
\hline & $(1.81)$ & $(5.18)$ & $(6.03)$ & $(1.96)$ & $(5.24)$ & $(5.77)$ \\
\hline \multirow{2}{*}{ Discount rates } & $0.05464^{\star \star}$ & -0.12168 & $-0.06787^{\star \star \star}$ & $0.04504^{*}$ & -0.12362 & -0.02143 \\
\hline & $(2.04)$ & $(1.24)$ & $(2.88)$ & $(1.68)$ & $(1.27)$ & $(0.84)$ \\
\hline \multirow{2}{*}{ Base lending rate } & $0.07884^{* \star \star}$ & 0.08210 & $-0.10026^{\star \star \star}$ & $0.07447^{\star \star *}$ & 0.05016 & $-0.09795^{\star \star \star}$ \\
\hline & (3.42) & $(0.57)$ & $(6.23)$ & (3.23) & $(0.34)$ & (6.13) \\
\hline \multirow{2}{*}{ Liquid ratio } & $6.50911^{\star \star \star}$ & $3.76100^{* \star \star}$ & $2.00782^{* \star \star}$ & 0.00000 & $3.74770^{\star \star \star}$ & $1.90455^{\star \star \star}$ \\
\hline & $(18.95)$ & $(4.85)$ & $(7.08)$ & $(19.01)$ & $(4.84)$ & $(6.55)$ \\
\hline \multirow{2}{*}{ Loss reserve to total lending ratio } & $0.11122^{\star \star \star}$ & $-0.25746^{*}$ & $0.06637^{\star \star \star}$ & $0.11190^{\star \star \star}$ & $-0.25957^{*}$ & $0.06727^{\star \star \star}$ \\
\hline & $(3.34)$ & $(1.81)$ & $(3.15)$ & $(3.36)$ & $(1.82)$ & $(3.19)$ \\
\hline \multirow{2}{*}{ Total assets growth rate } & $0.00692^{* \star \star}$ & $0.00640^{\star \star \star}$ & $0.01583^{\star \star \star}$ & $0.00694^{\star \star \star}$ & $0.00642^{* \star \star}$ & $0.01602^{\star \star \star}$ \\
\hline & $(11.07)$ & (9.13) & (12.18) & (11.13) & $(9.16)$ & (12.46) \\
\hline \multirow{2}{*}{ Lending to deposit ratio } & $-0.00912^{\star \star \star}$ & $-0.04600^{\star \star \star}$ & $-0.00207^{\star \star \star}$ & $-0.00907^{\star \star \star}$ & $-0.04578^{\star \star \star}$ & $-0.00204^{\star \star \star}$ \\
\hline & $(8.97)$ & $(14.06)$ & $(3.17)$ & $(8.94)$ & $(13.98)$ & (3.13) \\
\hline \multirow{2}{*}{ Credit-to-collateralized Lending } & $-0.00116^{\star \star \star}$ & $-0.26652^{*}$ & -0.00041 & $-0.00117^{\star \star \star}$ & $-0.27311^{*}$ & -0.00049 \\
\hline & $(3.17)$ & $(1.87)$ & $(1.12)$ & $(3.20)$ & $(1.92)$ & $(1.34)$ \\
\hline \multirow{2}{*}{ Credit-lending Herfindahl } & $3.83385^{\star \star *}$ & $1.72059^{\star *}$ & $-9.70925^{\star \star \star}$ & & & \\
\hline & $(5.19)$ & $(2.01)$ & $(4.35)$ & & & \\
\hline \multirow{2}{*}{ Collateralized-lending Herfindahl } & & & & $3.64713^{\star \star \star}$ & $1.42264^{* \star}$ & $-10.05430^{\star \star \star}$ \\
\hline & & & & (6.60) & $(2.28)$ & $(4.45)$ \\
\hline Observations & 5027 & 2233 & 2794 & 5027 & 2233 & 2794 \\
\hline Number of Banks & 32 & 29 & 32 & 32 & 29 & 32 \\
\hline R-squared & 0.54316 & 0.77128 & 0.28394 & 0.54468 & 0.77140 & 0.28416 \\
\hline
\end{tabular}

Note: Average monthly deposit and branch market shares are used as the explanatory variables of interest. The regression model uses fundamental bank information, excluding macroeconomic and lending practice information. Absolute value of $t$ statistics in parentheses * significant at $10 \%$; ** significant at 5\%; *** significant at $1 \%$.

As discussed earlier, this is a period of fierce pricing wars and industry consolidation, and the result may potentially be attributed to the rapid erosion of NIMs among banks. In other words, during this period, the Herfindahl indices became higher but NIMs continued to drop. This may yield a negative correlation between the Herfindahl indices and NIMs during the period. It also does not provide support for Bain's collusion hypothesis. 
Table 10. Herfindahls based on credit lending and collateralized lending - adding macroeconomic information

\begin{tabular}{|c|c|c|c|c|c|c|}
\hline & \multicolumn{3}{|c|}{ Herfindahl - credit-lending } & \multicolumn{3}{|c|}{ Herfindahl - collateralized-lending } \\
\hline & All & 1991 2000 & 2001 2009 & All & $1991 \sim 2000$ & 2001 2009 \\
\hline \multirow{2}{*}{ Debt-to-asset ratio } & $-0.04031^{\star \star \star}$ & $-0.02916^{\star \star \star}$ & $-0.06379^{\star \star \star}$ & $-0.04065^{\star \star \star}$ & $-0.03021^{\star \star *}$ & $-0.06255^{\star \star \star}$ \\
\hline & $(8.28)$ & $(4.42)$ & (9.62) & $(8.34)$ & $(4.60)$ & $(9.53)$ \\
\hline \multirow{2}{*}{ NPL percentage } & $0.06685^{\star \star \star}$ & 0.00901 & $0.13121^{\star \star \star}$ & $0.06660^{\star \star \star}$ & 0.00764 & $0.13297^{\star \star \star}$ \\
\hline & $(7.20)$ & $(0.56)$ & $(13.28)$ & $(7.18)$ & $(0.48)$ & $(13.46)$ \\
\hline \multirow{2}{*}{ Service interest to total income } & $3.95722^{\star \star \star}$ & $11.63221^{\star \star \star}$ & $1.32511^{\star \star \star}$ & $3.91325^{\star \star \star}$ & $11.74582^{\star \star \star}$ & $1.31578^{\star \star \star}$ \\
\hline & (7.58) & $(8.53)$ & $(2.75)$ & $(7.50)$ & $(8.62)$ & $(2.74)$ \\
\hline \multirow{2}{*}{ Administrative cost percentage } & $0.02467^{\star \star \star}$ & $0.15463^{\star \star \star}$ & $-0.02431^{\star \star \star}$ & $0.02511^{\star \star \star}$ & $0.15487^{\star \star \star}$ & $-0.02443^{\star \star \star}$ \\
\hline & $(7.01)$ & $(21.62)$ & $(6.49)$ & $(7.15)$ & $(21.63)$ & $(6.55)$ \\
\hline \multirow{2}{*}{ Discount rates } & 0.00160 & $0.16512^{*}$ & -0.04524 & -0.02531 & 0.13122 & -0.03350 \\
\hline & $(0.06)$ & $(1.81)$ & $(1.64)$ & $(1.09)$ & $(1.42)$ & $(1.29)$ \\
\hline \multirow{2}{*}{ Base lending rate } & $0.12929^{\star \star \star}$ & $0.18990^{\star \star}$ & $-0.06575^{\star \star \star}$ & $0.11783^{\star \star \star}$ & 0.15202 & $-0.05424^{\star \star \star}$ \\
\hline & $(6.78)$ & $(2.00)$ & $(3.64)$ & $(6.30)$ & $(1.60)$ & $(3.03)$ \\
\hline \multirow{2}{*}{ Liquid ratio } & $5.76833^{* \star \star}$ & $1.71499^{\star \star \star}$ & $2.32025^{* \star *}$ & $5.71518^{\star \star *}$ & $1.64677^{\star \star \star}$ & $2.18253^{\star \star \star}$ \\
\hline & $(20.71)$ & $(3.09)$ & $(7.86)$ & (20.59) & $(2.97)$ & $(7.48)$ \\
\hline \multirow{2}{*}{ Loss reserve to total lending } & $0.15220^{* * *}$ & $-0.28997^{\star \star *}$ & $0.04868^{\star *}$ & $0.15420^{\star \star *}$ & $-0.29282^{\star * *}$ & $0.04932^{* *}$ \\
\hline & $(6.30)$ & $(3.48)$ & (2.29) & $(6.38)$ & $(3.51)$ & $(2.33)$ \\
\hline \multirow{2}{*}{ Total assets growth rate } & $0.00958^{\star \star \star}$ & $0.01354^{\star \star \star}$ & $0.01505^{\star \star \star}$ & $0.00952^{\star \star \star}$ & $0.01354^{\star \star \star}$ & $0.01441^{* \star \star}$ \\
\hline & $(9.94)$ & $(11.67)$ & $(11.57)$ & $(9.89)$ & $(11.67)$ & $(11.06)$ \\
\hline \multirow{2}{*}{ Lending to deposit ratio } & $-0.00572^{* \star *}$ & $-0.02829^{* \star *}$ & $-0.00243^{\star * *}$ & $-0.00566^{\star \star *}$ & $-0.02828^{\star * *}$ & $-0.00234^{* \star *}$ \\
\hline & $(7.57)$ & $(12.04)$ & $(3.72)$ & $(7.50)$ & (12.03) & $(3.60)$ \\
\hline \multirow{2}{*}{ Credit-to-collateralized lending } & $-0.00099^{\star \star \star}$ & $-0.19844^{* *}$ & -0.00047 & $-0.00098^{\star \star \star}$ & $-0.18861^{* *}$ & -0.00046 \\
\hline & $(3.76)$ & $(2.12)$ & $(1.29)$ & $(3.70)$ & $(2.03)$ & $(1.26)$ \\
\hline \multirow{2}{*}{ Bank assets to GDP ratio } & $-10.80794^{\star \star \star}$ & $-22.04006^{\star \star \star}$ & $12.14298^{\star \star \star}$ & $-10.35129^{\star \star \star}$ & $-22.43156^{\star \star \star}$ & $8.17747^{\star \star}$ \\
\hline & (3.72) & $(5.88)$ & $(3.33)$ & $(3.54)$ & $(6.08)$ & $(2.16)$ \\
\hline \multirow{2}{*}{ GDP growth rate } & $-0.01437^{\star \star \star}$ & $-0.04412^{\star \star \star}$ & $0.01256^{\star \star \star}$ & $-0.01139^{\star \star}$ & $-0.04091^{\star \star *}$ & $0.00814^{*}$ \\
\hline & $(2.99)$ & $(3.15)$ & $(2.86)$ & $(2.34)$ & $(2.88)$ & $(1.78)$ \\
\hline \multirow{2}{*}{ Stock capitalization to GDP } & $-0.11895^{\star \star \star}$ & $0.86294^{\star \star \star}$ & $-0.03137^{\star \star}$ & $-0.10599^{\star \star \star}$ & $0.71459^{\star \star \star}$ & -0.01229 \\
\hline & $(8.35)$ & (3.49) & $(2.22)$ & $(7.71)$ & $(2.94)$ & $(0.88)$ \\
\hline \multirow{2}{*}{ Monthly total assets } & $0.72208^{\star \star \star}$ & $1.27794^{\star \star \star}$ & $0.43876^{* *}$ & $0.57346^{\star \star \star}$ & $1.16488^{\star \star \star}$ & $1.05276^{\star \star *}$ \\
\hline & (6.73) & $(7.08)$ & $(2.03)$ & $(5.75)$ & $(6.86)$ & $(3.61)$ \\
\hline \multirow{2}{*}{ Credit-lending Herfindahl } & $7.84642^{\star \star \star}$ & $6.08593^{\star \star \star}$ & -2.44353 & & & \\
\hline & $(6.81)$ & $(4.14)$ & $(0.80)$ & & & \\
\hline \multirow{2}{*}{ Collateralized-lending Herfindahl } & & & & $5.13710^{\star \star \star}$ & $3.69224^{\star \star \star}$ & $-12.50610^{\star \star \star}$ \\
\hline & & & & $(6.94)$ & $(4.17)$ & $(3.20)$ \\
\hline Observations & 4984 & 2191 & 2793 & 4984 & 2191 & 2793 \\
\hline Number of Banks & 32 & 29 & 32 & 32 & 29 & 32 \\
\hline R-squared & 0.29497 & 0.61507 & 0.29370 & 0.29522 & 0.61512 & 0.29615 \\
\hline
\end{tabular}

Note: Average monthly deposit and branch market shares are used as the explanatory variables of interest. The regression model uses fundamental bank information, lending practice and macroeconomic information. Absolute value of $t$ statistics in parentheses $*$ significant at $10 \% ; * *$ significant at $5 \% ; * * *$ significant at $1 \%$.

\section{Conclusions}

The overall results show that firm market shares tend to have positive and significant impacts on the bank NIMs. The credit lending market share is highly significant in affecting the level of NIMs, and its effect is stronger for the second sub-period. The focus of lending type shifted from collateralized to credit lending, and the results here indicate this shift as well. The collateralized lending market share, on the other hand, has significant impacts between 1999 and 2000, but it loses its significance from 2001 to 2009. This also indicates the shift of lending type. There is a dramatic period-to-period change in the statistical significance of the service income to total income ratio. As discussed earlier, banks may charge higher lending rates if they have a higher portion of income coming from service fees, and the results are highly significant in the period of 1991-2000. But the variable experiences a drop in significance for 2001-2009. The results show that, given this shift, in the second sub-period one can see that higher credit lending market share led to higher NIMs. The high credit lending market share increases demand for a bank's credit loans and raise the NIMs. It means that a relatively popular cash card or credit card may induce more potential customers to apply, raising the demand and resulting in higher lending rates. 


\section{References}

1. Akhavein, Jalal, D., Allen, N., Berger and David, B., Humphrey (1997). The Effects of Megamergers on Efficiency and Prices: Evidence from a Bank Profit Function, Review of Industrial Organization, 12(1), pp. 105-139.

2. Allen, Linda (1988). The Determinants of Bank Interest Margins: A Note, Journal of Financial and Quantitative Analysis, 23, pp. 231-235.

3. Bain, J.S. (1951). Relation of profit rate to industry concentration: American manufacturing, 1936-1940, The Quarterly Journal of Economics, pp. 293-324.

4. Barth, James, R., Daniel, E., Nolle and Tara, N., Rice (1997). Commercial Banking Structure, Regulation, and Performance: An International Comparison. Comptroller of the Currency Economics, Working Paper 97-6. Comptroller of the Currency, Washington, D.C.

5. Berger, Allen, N. (1995a). The Profit-Structure Relationship in Banking: Tests of Market-Power and Efficient Structure Hypotheses, Journal of Money, Credit, and Banking, 27(2), pp. 404-431.

6. Berger, Allen, N. (1995b). The Relationship between Capital and Earning in Banking, Journal of Money, Credit, and Banking, 27(2), 432-456.

7. Berger, Allen, N. and Timothy, H., Hannan (1989). The Price-Concentration Relationship in Banking, Review of Economics and Statistics, 71, pp. 291-299.

8. Buser, Stephen, A., Andrew, H., Chen and Edward, J., Kane (1981). Federal Deposit Insurance, Regulatory Policy, and Optimal Bank Capital, Journal of Finance, 35(1), pp. 51-60.

9. Demirgüç-Kunt, Ash and Harry, Huizinga (1999). Determinants of Commercial Banks Interest Margins and Profitability: Some International Evidence, World Bank Economic Review, 13(2), pp. 379-408.

10. Demirgüç-Kunt, Asli and Harry, Huizinga (2000). Financial Structure and Bank Profitability, World Bank Policy Research, Working Paper No. 2430.

11. Demirguiq-Kunt, Asli, Luc, Laeven, and Ross, Levine (2004). Regulations, Market Structure, Institutions, and the Cost of Financial Intermediation, Journal of Money, Credit, and Banking, 36, pp. 593-622.

12. Demsetz, H. (1973). Industry structure, market rivalry, and public policy, Journal of Law and Economics, pp. 1-9.

13. Focarelli, Dario and Fabio, Panetta (2003). Are Mergers Beneficial to Consumers? Evidence from the Market for Bank Deposits, The American Economic Review, 93(4), pp. 1152-1172.

14. Geithman, Frederick, E., Howard, P. Marvel and Leonard, W., Weiss (1980). Concentration, Price, and Critical Concentration Ratios, The Review of Economics and Statistics, 63(3), pp. 346-353.

15. Hannan, Timothy, H. and Allen, N., Berger (1991). The Rigidity of Prices: Evidence from the Banking Industry, American Economic Review, 81, pp. 938-945.

16. Hannan, Timothy, H. and Robin, A., Prager (2004). The Competitive Implications of Multimarket Bank Branching, Journal of Banking and Finance, 28, pp. 1889-1914.

17. Hanson, James, A. and Roberto de Rezende Rocha (1986). High Interest Rates, Spreads, and the Cost of Intermediation: Two Studies, Industry and Finance Series 18. World Bank, Industry Department, Washington, D.C.

18. Hart, O., Zingales, L. (2014). Banks are where the liquidity is. NBER Working Paper No. 20207.

19. Ho, Thomas and Anthony, Saunders (1981). The Determinants of Bank Interest Margins: Theory and Empirical Evidence, Journal of Financial and Quantitative Analysis, 4, pp. 581-600.

20. Huang, Seth Hao-Ting (2010). Essays On Firms Behaviors And Efficiencies. Ph.D. Disseration, Cornell University.

21. Hwang, Dar-Yeh and Wei-Hsiung Wu (2007). Financial system reform in Taiwan, Journal of Asian Economics, 18(1), pp. 21-41.

22. Masson, Robert, G., Jakubson, K., Jeong and D., Kim (2009). Cycles in Economic Activity, Industrial Structure and Price-Cost Margins: A New Methodology Using a Structural Model. Working paper, Cornell University.

23. Peria, Maria Soledad Martinez and Ashoka Mody (2004). How Foreign Participation and Market Concentration Impact Bank Spreads: Evidence from Latin America, Journal of Money, Credit and Banking, 36(3), pp. 511-537.

24. Prager, Robin A. and Timothy H. Hannan (1998). Do Substantial Horizontal Mergers Generate Significant Price Effects? Evidence from the Banking Industry, The Journal of Industrial Economics, 46(4), pp. 433-452.

25. Salas, Vicente and Jesús Saurina (2002). Credit Risk in Two Institutional Regimes: Spanish Commercial and Savings Banks, Journal of Financial Services Research, 22(3), pp. 203-224.

26. Sapienza, Paola (2004). The Effects of Government Ownership on Bank Lending, Journal of Financial Economics, 72, pp. 357-384.

27. Scherer, F.M. and D. Ross (1990). Industrial Market Structure and Economic Performance (3rd ed.). Houghton Mifflin, Boston, MA.

28. Wong, Kit Pong (1997). On the Determinants of Bank Interest Margins under Credit and Interest Rate Risks, Journal of Banking and Finance, 21, pp. 251-271.

29. Zarruck, Emilio R. (1989). Bank Margin with Uncertain Deposit Level and Risk Aversion, Journal of Banking and Finance, 14, pp. 803-820. 